\title{
TLR4 mutation reduces microglial activation, increases $A \beta$ deposits and exacerbates cognitive deficits in a mouse model of Alzheimer's disease
}

\author{
Min Song ${ }^{1,2+}$, JingJi Jin ${ }^{1 \dagger}$, Jeong-Eun Lim', Jinghong Kou', Abhinandan Pattanayak', Jamaal A Rehman', \\ Hong-Duck Kim³ ${ }^{3}$ Kazuki Tahara', Robert Lalonde ${ }^{4,5}$ and Ken-ichiro Fukuchi ${ }^{{ }^{*}}$
}

\begin{abstract}
Background: Amyloid plaques, a pathological hallmark of Alzheimer's disease (AD), are accompanied by activated microglia. The role of activated microglia in the pathogenesis of AD remains controversial: either clearing A $\beta$ deposits by phagocytosis or releasing proinflammatory cytokines and cytotoxic substances. Microglia can be activated via toll-like receptors (TLRs), a class of pattern-recognition receptors in the innate immune system. We previously demonstrated that an AD mouse model homozygous for a loss-of-function mutation of TLR4 had increases in $A \beta$ deposits and buffer-soluble $A \beta$ in the brain as compared with a TLR4 wild-type AD mouse model at 14-16 months of age. However, it is unknown if TLR4 signaling is involved in initiation of A $\beta$ deposition as well as activation and recruitment of microglia at the early stage of AD. Here, we investigated the role of TLR4 signaling and microglial activation in early stages using 5-month-old AD mouse models when A $\beta$ deposits start.
\end{abstract}

Methods: Microglial activation and amyloid deposition in the brain were determined by immunohistochemistry in the AD models. Levels of cerebral soluble A $\beta$ were determined by ELISA. mRNA levels of cytokines and chemokines in the brain and $A \beta$-stimulated monocytes were quantified by real-time PCR. Cognitive functions were assessed by the Morris water maze.

Results: While no difference was found in cerebral A $\beta$ load between AD mouse models at 5 months with and without TLR4 mutation, microglial activation in a TLR4 mutant AD model (TLR4M Tg) was less than that in a TLR4 wild-type AD model (TLR4W Tg). At 9 months, TLR4M Tg mice had increased A $\beta$ deposition and soluble A 42 in the brain, which were associated with decrements in cognitive functions and expression levels of IL-1 $\beta, C C L 3$, and CCL4 in the hippocampus compared to TLR4W Tg mice. TLR4 mutation diminished A $\beta$-induced IL-1 $\beta$, CCL3, and CCL4 expression in monocytes.

Conclusion: This is the first demonstration of TLR4-dependent activation of microglia at the early stage of $\beta$ amyloidosis. Our results indicate that TLR4 is not involved in the initiation of A $\beta$ deposition and that, as A deposits start, microglia are activated via TLR4 signaling to reduce $A \beta$ deposits and preserve cognitive functions from $A \beta$-mediated neurotoxicity.

\section{Background}

Alzheimer's disease (AD) is a progressive dementing disorder characterized by $A \beta$-containing amyloid plaques, intracellular neurofibrillary tangles and degenerating neurons in the brain. Most mutations in the $A \beta$-protein

\footnotetext{
* Correspondence: kfukuchi@uic.edu

† Contributed equally

'Department of Cancer Biology and Pharmacology, University of Illinois

College of Medicine at Peoria, P.O. Box 1649, Peoria, IL 61656, USA

Full list of author information is available at the end of the article
}

precursor (APP) and presenilin (PS1 and PS2) genes, which are associated with familial $A D$, increase production of $A \beta$, particularly the 42-amino-acid form of $A \beta$ $(A \beta 42)$ in the brain $[1,2]$. Aggregated $A \beta$ is thought to be toxic to neurons in the brain and overexpression of APP with these mutations induces AD-like pathology in mice. One of the important consequences of $A \beta$ deposits in the brain is recruitment and activation of microglia. Microglia function as an immunosurveillance cell

\section{Biomed Central}

(c) 2011 Song et al; licensee BioMed Central Ltd. This is an Open Access article distributed under the terms of the Creative Commons Attribution License (http://creativecommons.org/licenses/by/2.0), which permits unrestricted use, distribution, and reproduction in any medium, provided the original work is properly cited. 
in the central nervous system and play important roles in maintaining immune homeostasis. Accumulating studies, however, indicate that activated microglia is a double-edged sword. They are able to protect neurons from toxic substances such as aggregated $A \beta$ by taking up and degrading them while activated microglia release proinflammatory cytokines, chemokines, and reactive oxygen and nitrogen species, which can be harmful to synapses and neurons [3-5]. Therefore, it is of great importance to elucidate the mechanism by which these phenotypes of activated microglia are regulated for development of therapeutic strategies.

Toll-like receptors (TLRs) are first-line molecules for initiating innate immune responses. When activated through TLR signaling, microglia/macrophages respond to pathogens and damaged host cells by secreting chemokines and cytokines and express co-stimulatory molecules needed for protective immune responses to pathogens and efficient clearance of damaged tissues [6]. Fibrillar $A \beta$ has been shown to activate microglia via cell surface receptor complexes that involve several toll-like receptors as essential components in vitro [7-9]. We previously demonstrated that an AD mouse model homozygous for a nonfunctional (loss-of-function) mutation of TLR4 had increases in diffuse and fibrillar $A \beta$ deposits as well as buffer-soluble and insoluble $A \beta$ in the brain as compared with a TLR4 wildtype AD mouse model (TgAPPswe/PS1dE9 mice) at 14-16 months of age [10]. We also showed that $A \beta$ induced upregulation of certain cytokines and chemokines in the brain of the same model at 13-15 months of age was mediated by TLR4 signaling [11]. This AD mouse model starts to develop $A \beta$ deposits in the brain at around 5 months of age. However, it is not clear if microglia are activated in the early stages of AD (reviewed in Wyss-Coray [3]). Heneka et al. [12] even suggested that microglia may be activated before any amyloid deposits are formed. Recently, using in vivo multiphoton microscopy and 5- to 6-month-old TgAPPswe/PS1dE9 mice, Meyer-Luehmann et al. [13] reported that amyloid plaques formed extraordinarily quickly over 24 hours and that within 1-2 days of appearance of new plaque, microglia were activated and recruited to the site. On the other hand, Yan et al. [14] reported that amyloid plaques appeared and grew over a period of weeks before reaching a mature size in 6-month-old AD model mice. It is unknown if TLR4 signaling is involved in activation and recruitment of microglia and if TLR4 signaling is neuroprotective or harmful at the early stage of $A D$ when $A \beta$ deposits start. Therefore, in this study we investigated $\mathrm{A} \beta$ deposition and microglial activation in the TLR4 mutant and wild-type AD mouse models at 5 months of age in order to elucidate a possible role of TLR4 signaling and microglial activation in early stages of $\mathrm{AD}$ pathogenesis.

\section{Methods \\ Animals}

Pathogen-free transgenic mice of an AD model, TgAPPswe/PS1dE9 mice [B6C3-Tg(APPswe,PSEN1dE9) 85Dbo/J, strain name at Jackson] [15], and B6C3F1 mice were purchased from Jackson Laboratory (Bar Harbor, $\mathrm{ME})$. The transgenic mice express chimeric mouse/ human APP with the double mutations (K670N and M671L) and human PS1 with a deletion of exon 9 found in familial AD patients. The transgenic mice have been maintained by mating with $\mathrm{B} 6 \mathrm{C} 3 \mathrm{~F} 1$ mice. $\mathrm{C} 3 \mathrm{H} /$ $\mathrm{HeJ}$ mice are highly susceptible to Gram-negative infection and resistant to bacterial lipopolysaccharide (LPS) due to a destructive mutation of the TLR4 gene $\left(\mathrm{TLR} 4^{\mathrm{Lps}-\mathrm{d}}\right)$. The TLR4 genotype was determined by polymerase chain reaction (PCR) followed by restriction enzyme digestion with Nla III as described previously [10]. In this study, four experimental groups at the ages of 5 and 9 months were used: 1) homozygous TLR4 mutant TgAPPswe/PS1dE9 transgenic mice (TLR4M Tg), 2) TLR4 wild-type transgenic mice (TLR4W Tg), 3) homozygous TLR4 mutant non-transgenic littermates (TLR4M non-Tg), and 4) TLR4 wild type non-transgenic mice (TLR4W non-Tg) $(n=8-11 /$ group at each age). Half of the mice were deeply anesthetized and perfused transcardially with cold PBS followed by $4 \%$ paraformaldehyde and processed for histochemical and immunohistochemical analyses. Half of the mice were euthanized and their brains were processed for biochemical analyses. Nine month-old mice $(\mathrm{n}=10$-11/ group) were subjected to the Morris water maze test. A separate set of TLR4W $(n=6)$ and TLR4M $(n=5)$ Tg mice at 5 months of age were used for extraction of RNA. Another separate set of TLR4W $(n=7)$ and TLR4M $(\mathrm{n}=4)$ Tg mice at 9 months of age were also used for biochemical analyses (protein and mRNA). All animal protocols used for this study were prospectively reviewed and approved by the Institutional Animal Care and Use Committee of the University of Illinois College of Medicine at Peoria.

\section{Morris water maze behavioral test}

Acquisition of spatial learning in the Morris water maze was assessed during 5 consecutive days. The Morris water maze consisted of a pool (diameter: $112 \mathrm{~cm}$, wall height: $75 \mathrm{~cm})$ filled with water $\left(21^{\circ} \mathrm{C}\right)$ at a height of 31 $\mathrm{cm}$. Powdered milk was evenly spread over the water surface in order to camouflage the escape platform (10 $\mathrm{cm} \times 10 \mathrm{~cm}$ ) made of white plastic and covered with a wire mesh grid to ensure a firm grip. The pool was contained in a room with visual cues such as light fixtures 
and a ladder. The mice were placed next to and facing the wall successively in north $(\mathrm{N})$, east $(\mathrm{E})$, south $(\mathrm{S})$, and west $(\mathrm{W})$ positions, with the escape platform hidden $1 \mathrm{~cm}$ below water level in the middle of the NW quadrant. An overhead video-camera and SmartTM videotracking software (San Diego, CA) were used to estimate path length and escape latencies in 4 trial sessions for 5 days with approximately $20 \mathrm{~min}$ intertrial intervals. Whenever the mice failed to reach the escape platform within $1 \mathrm{~min}$, the mice were guided to the platform and remained on it for 5 seconds. The day after the acquisition phase, a probe trial was conducted by removing the platform and placing the mouse next to and facing the $\mathrm{N}$ side. The time spent in the previously correct quadrant was measured for a single $1 \mathrm{~min}$ trial. After the probe trial, the visible platform subtask was conducted, with the escape platform lifted $1 \mathrm{~cm}$ above water level and shifted to the SE quadrant. A $17 \mathrm{~cm}$ high pole was inserted on top of the escape platform as a viewing aid. With the exception that the subtest was conducted in a single day, the same procedure was adopted as with the acquisition phase.

\section{Immunohistochemistry, histochemistry and quantification of $A \beta$ deposits and activated glial cells}

Frozen serial sections ( $5 \mu \mathrm{m}$ thick) were cut and subjected to immunohistochemistry using the avidin-biotinperoxidase method (VECTASTAIN ABC Kit). Endogenous peroxidase was eliminated by treatment with $3 \%$ $\mathrm{H}_{2} \mathrm{O}_{2} / 10 \%$ methanol Tris-buffered saline (TBS) for 20 min at room temperature. After washing with water and 0.1 M TBS ( $\mathrm{pH} 7.4$ ), slides were blocked with $2 \%$ bovine serum albumin (BSA) and $2 \%$ goat serum in $0.1 \%$ triton-X-100 TBS (TBST) buffer for $60 \mathrm{~min}$ at room temperature to prevent non specific protein binding. The slides were then incubated with primary antibody 6E10 (1: 2000; Signet Laboratories, Dedham, MA) or CD11b (1:200; Serotec, MCA711, Raleigh, NC) in 2\% BSA, $2 \%$ goat serum TBST overnight at $4^{\circ} \mathrm{C}$. The sections were rinsed in $0.1 \mathrm{M}$ TBST containing $0.1 \% \mathrm{BSA}$ and incubated with biotinylated secondary antibody anti-mouse IgG (1: 400) for 6E10 or anti-rat IgG (1:200) for CD11b in $2 \% \mathrm{BSA}, 1 \%$ goat serum TBST for $1 \mathrm{~h}$ at room temperature. Finally, the avidin biotin peroxidase method using 3,3'-diaminobenzidine as a substrate (Vector, Burlingame, CA) was performed according to manufacturer's protocol. For the negative control, slides were processed with isotype control antibodies (mouse IgG1 for $6 \mathrm{E} 10$ and rat IgG2b for CD11b) (BD Biosciences, San Jose, CA) to ensure specific staining by primary antibodies. Some sections were counterstained with hematoxylin. Brain sections were also stained with $1 \%$ thioflavin $\mathrm{S}$ followed by destaining in $70 \%$ ethanol for detection of $A \beta$ fibrils.
Histomorphometry for quantification of amyloid deposition and microglial activation was performed using an Olympus BX61 automated microscope, Olympus Fluoview system and the Image Pro Plus v4 image analysis software (Media Cybernetics, Silver Spring, MD) capable of color segmentation and automation via programmable macros. Each brain section was entirely constructed from pictures that were taken using a $10 \mathrm{X}$ objective and $1 \mathrm{X}$ eyepiece lens in order to ensure no overlap. Six coronal brain sections from each mouse were analyzed, each separated by an approximately 250 $\mu \mathrm{m}$ interval, starting at $1.6 \mathrm{~mm}$ posterior to the bregma to caudal. Areas stained by 6E10, CD11b and thioflavin $\mathrm{S}$ were measured using Image Pro Plus v4 image analysis software and expressed as a percentage of total hippocampus or neocortex examined.

For double-label fluorescence immunohistochemistry, after quenching autofluorescence by $10 \mathrm{mg} / \mathrm{ml}$ sodium borohydride $(\mathrm{NaBH} 4)$ and/or $0.05 \%$ Sudan Black B, brain sections were subjected to double-label fluorescence immunohistochemistry. For 6E10- and CD11bdouble-label fluorescence, brain sections were incubated with these antibodies followed by incubation with Alexa Fluoro 594-conjugated chicken anti-mouse IgG antibody and Alexa Fluoro 488-conjugated goat-anti-rat IgG antibody, respectively. For TLR4-, CD11b, CD45-, and GFAP-double-label fluorescence, the sections were incubated overnight with rat anti-TLR4/MD2 antibody (eBioscience, San Diego, CA). After washing, the sections were incubated with chicken anti-rat IgG antibody conjugated with Alexa Fluoro 488 (Invitrogen, Carlsbad, CA) for $2 \mathrm{~h}$. After washing, the same sections were similarly treated with rabbit anti- CD11b (Santa Cruz Biotechnology), anti-CD45 (Santa Cruz Biotechnology) or rabbit anti-GFAP (astrocytic marker: G-9269, Sigma) antibody followed by incubation with chicken anti-rabbit IgG Alexa Fluoro 594 conjugated secondary antibody (Invitrogen). Some sections were stained with CD11b antibody (MCA711) using the avidin-biotin-peroxidase method as described above and then subjected to thioflavin S staining. After washing, the sections were observed under Olympus IX71 automated fluorescence microscope. The pictures were taken through an Olympus DP70 digital camera system.

\section{Quantification of buffer soluble brain $A \beta$ by ELISA}

Using the left cerebral hemispheres, the brain tissues were dounce-homogenized in carbonate buffer $(100 \mathrm{mM}$ $\mathrm{Na}_{2} \mathrm{CO}_{3}, 50 \mathrm{mM} \mathrm{NaCl}, \mathrm{pH}$ 11.5) containing protease inhibitors $[10 \mu \mathrm{g} / \mathrm{ml}$ aprotinin and $1 \mathrm{mM} 4$-(2-aminoethyl) benzenesulphonyl fluoride hydrochloride (AEBSF)] and centrifuged at $16,000 \mathrm{~g}$ for $30 \mathrm{~min}$ at $4^{\circ} \mathrm{C}$. Protein concentrations in the supernatants were determined by Bio-Rad Protein Assay (Bio-Rad Laboratories, 
Hercules, CA), and levels of buffer-soluble $A \beta$ were determined by $A \beta 42$ and $A \beta 40$ enzyme-linked immunosorbent assay (ELISA) kits (Invitrogen) according to the manufacturer's protocol. A duplicate sample from each mouse was used for quantification.

\section{Quantification of cytokine and chemokine mRNA by real- time PCR}

The neocortex and hippocampus were separately isolated and soaked in RNAlater ${ }^{\mathbb{R}}$ Tissue Collection: RNA Stabilization Solution (Ambions, Austin, TX) at $4{ }^{\circ} \mathrm{C}$ overnight and then moved to $-80^{\circ} \mathrm{C}$. These tissues were homogenized in Trizol reagent (Invitrogen) for isolation of RNA. RNA samples were treated with RNase-Free DNase (Qiagen, Valencia, CA) for $15 \mathrm{~min}$ at room temperature, and total RNA was purified using QIAGEN RNeasy columns. Complementary DNA (cDNA) was generated from $2 \mu \mathrm{g}$ total RNA in a total volume of 20 $\mu l$ using SuperScript ${ }^{\circledR}$ III First-Strand Synthesis Kit (Invitrogen) according to the manufacturer's protocol. mRNA levels of interleukin (IL)-1 $\alpha$, IL-1 $\beta$, IL-4, IL-6, tumor necrosis factor (TNF)- $\alpha$, transforming growth factor (TGF) $-\beta$, interferon (IFN)- $\gamma$, CCL2 (MCP-1), CCL3 (MIP-1 $\alpha$ ), CCL4 (MIP-1 $\beta$ ) and CCL6 (C10) in the neocortex and hippocampus were determined by realtime PCR using an iCycler Thermal Cycler (Bio-Rad, Hercules, CA). Complementary DNA (cDNA) was amplified using FastStart SYBR Green Master mix (Roche Applied Science, Indianapolis, IN) with primers listed in Table 1. The PCR amplifications were performed as follows: $10 \mathrm{~min}$ preincubation at $95^{\circ} \mathrm{C}$ to activate the FastStart Taq DNA polymerase, 40 cycles of denaturation at $95^{\circ} \mathrm{C}$ for $15 \mathrm{~s}$, and primer annealing and extension for $1 \mathrm{~min}$ at $60^{\circ} \mathrm{C}$. PCR product melting curves were examined to confirm the homogeneity of PCR products. mRNA levels of cytokines and chemokines were normalized by subtracting cycle threshold
$(\mathrm{Ct})$ values obtained with GAPDH mRNA and expressed as $2^{-\Delta \mathrm{Ct}}[\Delta \mathrm{Ct}=\mathrm{Ct}$ (cytokine or chemokine) $-\mathrm{Ct}$ $(\mathrm{GAPDH})]$.

\section{Isolation of $\mathrm{CD} 11 \mathrm{~b}^{+}$splenocytes by flow cytometry}

Spleens were individually isolated from 2-month old TLR4M and TLR4W Tg mice. Single cell suspension of splenocytes was prepared by homogenizing a spleen tissue in $10 \mathrm{ml}$ of RPMI 1640 medium and forcing cells through a cell strainer with $70 \mu \mathrm{m}$ pores. Splenocytes were centrifuged at $200 \mathrm{~g}$ for $5 \mathrm{~min}$ and suspended with $0.8 \mathrm{ml}$ ACK lysing buffer (UAB Comprehensive Cancer Center) to lyse red blood cells. Cell suspension was centrifuged again at $300 \mathrm{~g}$ for $5 \mathrm{~min}$ and final cell pellets were suspended in $1 \times$ PBS containing $1 \%$ BSA. Cells were adjusted to $1 \times 10^{7}$ cells $/ \mathrm{ml}$ and incubated with 1 $\mu \mathrm{g} / \mathrm{ml}$ of PE rat anti-mouse CD11b (BD Pharmingen) at $4^{\circ} \mathrm{C}$ for $40 \mathrm{~min}$ in the dark. Then, cells were washed twice with $1 \times$ PBS containing $1 \%$ BSA and centrifuged at $300 \mathrm{~g}$ for $5 \mathrm{~min}$. The pellets were re-suspended in 1 $\times$ PBS containing $1 \%$ BSA at a concentration of $1 \times 10^{7}$ cells $/ \mathrm{ml}$. The cells were sorted into $\mathrm{CD}_{1} 1 \mathrm{~b}^{+}$and $\mathrm{CD}_{11 \mathrm{~b}^{-/ \text {low }}}$ population by the FACSCalibur System (Becton-Dickinson Bioscience, Rockville, MD).

\section{Treatment of $C D 11 b^{+}$monocytes with fibrillar $A \beta$}

Synthetic A $\beta 42$ was purchased from Anaspec (Anaspec Inc, San Jose, $\mathrm{CA}$ ). Fibrillar $\mathrm{A} \beta$ was prepared as described previously [16]. The peptide was dissolved in $1 \mathrm{mM}$ hexafluoroisopropanol (Sigma) and then dried under vacuum in a Speed Vac (Savant, Holbrook, NY). The residual peptide was re-suspended in dimethyl sulfoxide to a concentration of $5 \mathrm{mM}$. Fibrillar $\mathrm{A} \beta$ was made by adding 10 $\mathrm{mM} \mathrm{HCl}$ to a concentration of $100 \mu \mathrm{M}$ and incubated at $37^{\circ} \mathrm{C}$ for $24 \mathrm{~h}$. CD $11 \mathrm{~b}^{+}$splenocytes from TLRM and TLR4W Tg mice were plated at the density of $2.5 \times 10^{5}$ cells $/ \mathrm{ml}$ and incubated with $1 \mu \mathrm{M}$ fibrillar $\mathrm{A} \beta$ for $4 \mathrm{~h}$.

Table 1 DNA primer sequences for real-time PCR

\begin{tabular}{|c|c|c|}
\hline Gene & Forward primer $\left(5^{\prime}\right.$ to $\left.3^{\prime}\right)$ & Reverse primer $\left(5^{\prime}\right.$ to $\left.3^{\prime}\right)$ \\
\hline IL-1 $\alpha$ & AGGAGAGCCGGGTGACAGTA & AACTCAGCCGTCTCTTCTTCAGA \\
\hline$\underline{\mathrm{IL}-1 \mathrm{~B}}$ & TGGTGTGTGACGTTCCCATT & CAGCACGAGGCTIIITGTTG \\
\hline IL-4 & ACAGGAGAAGGGACGCCAT & GAAGCCCTACAGACGAGCTCA \\
\hline$\underline{\mathrm{IL}-6}$ & GAGGATACCACTCCCAACAGACC & AAGTGCATCATCGTTGTTCATACA \\
\hline$\underline{\mathrm{IL}-10}$ & GGTTGCCAAGCCTTATCGGA & ACCTGCTCCACTGCCTTGCT \\
\hline TNF- $\alpha$ & TCCAGGCGGTGCCTATGT & CGATCACCCCGAAGTTCAGTA \\
\hline TGF- $\beta$ & TGACGTCACTGGAGTTGTACGG & GGTTCATGTCATGGATGGTGC \\
\hline $\mathrm{IFN}-\gamma$ & TGAACGCTACACACTGCATCTTG & GTATTCAGACTITCTAGGCTTCAATG \\
\hline $\mathrm{CCL} 2$ & TGAATGTGAAGTTGACCCGT & AAGGCATCACAGTCCGAGTC \\
\hline CCL3 & CCTCTGTCACCTGCTCAACA & GATGAATTGGCGTGGAATCT \\
\hline CCL4 & CCCACTTCCTGCTGTTTCTC & GAGGAGGCCTCTCCTGAAGT \\
\hline CCL6 & GCCACACAGATCCCATGTAA & GCAATGACCTTGTTCCCAGA \\
\hline
\end{tabular}


Cells were harvested and RNA was extracted in Trizol reagent as described above. Complementary DNA (cDNA) was generated from $1 \mu \mathrm{g}$ total RNA in a total volume of $20 \mu \mathrm{l}$ using SuperScript ${ }^{\circledR}$ III First-Strand Synthesis Kit according to the manufacturer's protocol. The experiment was performed in triplicate for each condition. mRNA levels of IL- $1 \alpha$, IL-1 $\beta$, IL-6, CCL3, CCL4 were determined by real-time PCR as described above.

\section{Statistical analysis}

Data were expressed as mean \pm standard error of the mean (SEM). Intergroup differences were assessed by a repeated measures analysis of variance (ANOVA) and two-tailed Student's t-test for normally distributed data. For the probe trial of the Morris water maze, the MannWhitney rank sum test was used for comparison. $P \leq$ 0.05 was considered statistically significant.

\section{Results}

TLR4 mutation does not influence $A \beta$ load in the brain of an AD mouse model at 5 months of age but diminishes microglial activation

TLR4W Tg mice start to develop A $\beta$ deposits in the brain around the age of 5 months. To investigate if TLR4 signaling is involved in initiation of $A \beta$ deposition and microglial activation at the early stage of $\mathrm{AD}$, we determined $A \beta$ load and microglial activation in the TLR4W $(\mathrm{n}=5)$ and TLR4M $(\mathrm{n}=7)$ Tg mice at 5 months. Diffuse and fibrillar $A \beta$ deposits were detected by immunohistochemistry using $6 \mathrm{E} 10$ antibody that specifically reacts with human $\mathrm{A} \beta$ (Figure 1A and $1 \mathrm{~B}$ ) and were expressed by average percentages of areas showing $A \beta$ immunoreactivity in the cerebral cortex (Figure 1E). No difference was found in $\mathrm{A} \beta$ load between TLR4W $(0.243 \pm 0.045 \%)$ and TLR4M $(0.196 \pm 0.030 \%)$ Tg mice $(P>0.05)$.

Activated microglia/myeloid cells in the cerebral cortex were immunostained for expression of CD11b (Mac1) (Figure $1 \mathrm{C}$ and $1 \mathrm{D}$ ) and the immunoreactive areas were quantified (Figure 1F). CD11b-immunoreactivity $(0.237 \pm 0.043 \%)$ in TLR4W Tg mice was greater than that $(0.087 \pm 0.011 \%)$ in TLR4M Tg mice $(P=0.001)$. The ratio of $\mathrm{CD} 11 \mathrm{~b}$-immunoreactive area to $6 \mathrm{E} 10$ immunoreactive area in TLR4W Tg mice (0.921 \pm $0.133)$ was greater than that in TLR4M Tg mice $(0.459$ $\pm 0.049, P=0.006$ ) (Figure $1 G$ ).

To confirm this reduction in CD11b-positive microglia in TLR4M Tg mice, we carried out double immunofluorescence staining of brain sections from Tg mice using antiCD11b antibody (green) and anti-A $\beta$ antibody (red) (Figure $1 \mathrm{H}$ and $1 \mathrm{I})$. Most A $\beta$ deposits in TLR4W Tg mice were closely associated with microglia showing high expression of $\mathrm{CD} 11 \mathrm{~b}$ and some degree of overlap was found in double immunofluorescence images (Figure $1 \mathrm{H}$ ), suggesting uptake of $\mathrm{A} \beta$ by activated microglia. On the contrary, expression of
CD11b in microglia closely associated with $A \beta$ deposits was limited in TLR4 M Tg mice (Figure 1I).

To investigate if the TLR4 mutation alters production of $A \beta$ in the brain, we determined levels of buffer-soluble $A \beta 40$ and $A \beta 42$ by ELISA in early stages of amyloidogenesis. There was no difference between TLR4W (n =4) and TLR4M $(n=6)$ Tg mice at 5 months of age in the cerebral buffer-soluble A $\beta 40(24.1 \pm 3.4$ and $27.3 \pm$ $8.6 \mathrm{pg} / \mathrm{mg}$ protein, respectively) and $\mathrm{A} \beta 42(19.1 \pm 4.0$ and $17.6 \pm 7.2 \mathrm{pg} / \mathrm{mg}$ protein, respectively) content.

\section{TLR4 mutation increases $A \beta$ deposits as well as soluble $A \beta 42$ in the brain of an AD mouse model at 9 months of age}

We previously reported that cerebral $A \beta$ load increased in TLR4M Tg mice as compared to TLR4W Tg mice at 14-16 months of age [10] but we did not find such an increase at 5 months of age. Therefore, we further examined $\mathrm{A} \beta$ load in these AD mouse models at 9 months of age. Diffuse and fibrillar A $\beta$ deposits were detected by immunohistochemistry using 6E10 antibody (Figure $2 \mathrm{~A}$ and $2 \mathrm{~B}$ ) and $\mathrm{A} \beta$ loads were expressed by average percentage of areas showing $A \beta$ immunoreactivity in the hippocampus and neocortex (Figure 2G and $2 \mathrm{H})$. The $\mathrm{A} \beta$ loads in the neocortex $(2.20 \pm 0.15 \%)$ and hippocampus $(1.42 \pm 0.27 \%)$ increased in TLR4M Tg mice as compared to TLR $4 \mathrm{~W}$ Tg mice $(1.40 \pm 0.15 \%, P$ $<0.005$ for the neocortex and $1.08 \pm 0.06 \%, P<0.01$ for the hippocampus, $n=6$ for each group). Fibrillar $A \beta$ deposits were visualized by thioflavin $S$ fluorescence (Figure $2 \mathrm{C}$ and $2 \mathrm{D}$ ). The $\mathrm{A} \beta$ load in TLR4M Tg mice $(0.728 \pm 0.064 \%$ for the neocortex and $0.601 \pm 0.080 \%$ for the hippocampus) was greater than that in TLR4W Tg mice $(0.487 \pm 0.056 \%, P=0.021$ for the neocortex and $0.368 \pm 0.033 \% ; P=0.026$ for the hippocampus, $\mathrm{n}=$ 6 for each group) (Figure 2I and 2J).

Activated microglia/myeloid cells in the neocortex and hippocampus were immunostained for expression of CD11b (Figure 2E and 2F) and immunoreactive areas were quantified (Figure $2 \mathrm{~K}$ and $2 \mathrm{~L}$ ). There was no difference in expression levels of CD11b between TLR4W and TLR4M Tg mice. No difference was found between the two groups in the ratios of CD11b-immunoreactive area to $6 \mathrm{E} 10$-immunoreactive area (Figure $2 \mathrm{M}$ and $2 \mathrm{~N}$ ).

Levels of buffer-soluble $A \beta$ in the cerebrum of TLR4M Tg mice increased at 14-16 months of age as compared to TLR4W Tg mice [10] but not at 5 months of age. Therefore, we further determined levels of buffer-soluble $A \beta$ in the two Tg mouse groups at 9 months by $A \beta 40$ - and A 342 -specific sandwich ELISA. The cerebral buffer-soluble A $\beta 42$ content in TLR4M Tg mice $(597.8 \pm 21.3 \mathrm{pg} / \mathrm{mg}$ protein, $\mathrm{n}=4)$ was significantly higher than that in TLR4W Tg mice $(278.3 \pm 79.3 \mathrm{pg} /$ mg protein, $\mathrm{n}=4, P<0.01$ ) while there was no 

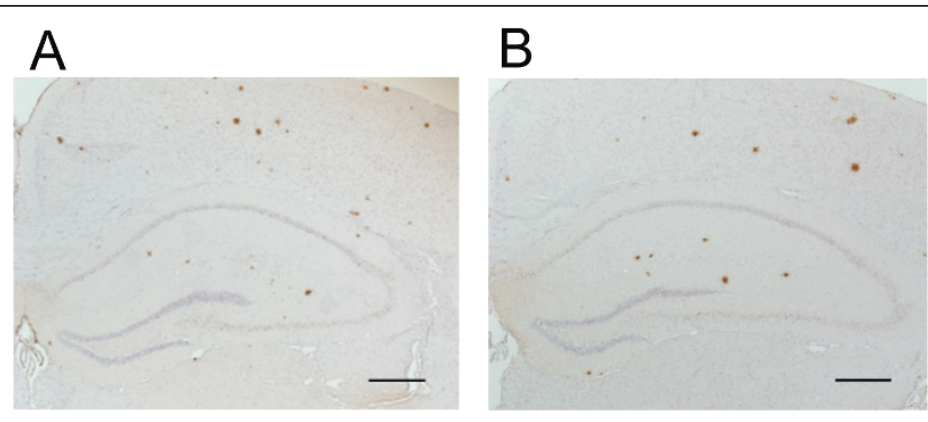

C

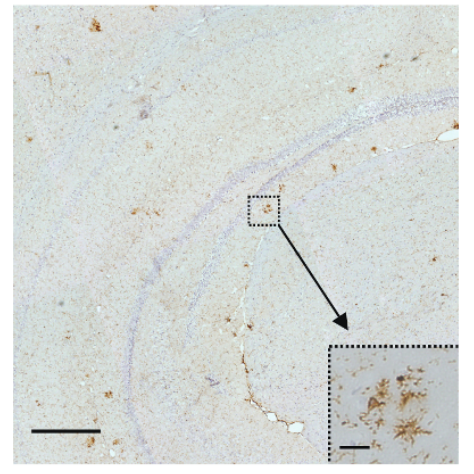

\section{D}

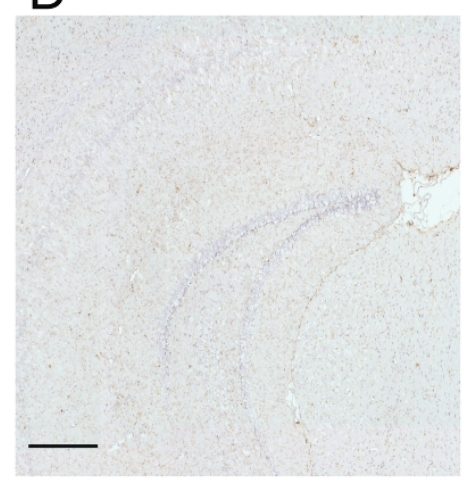

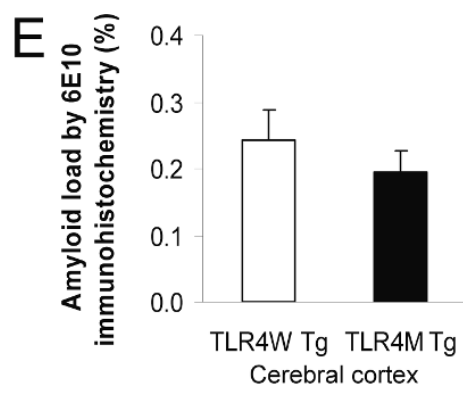
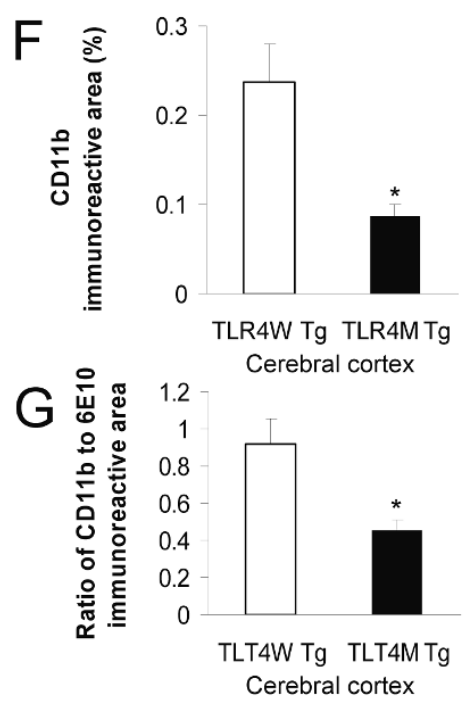

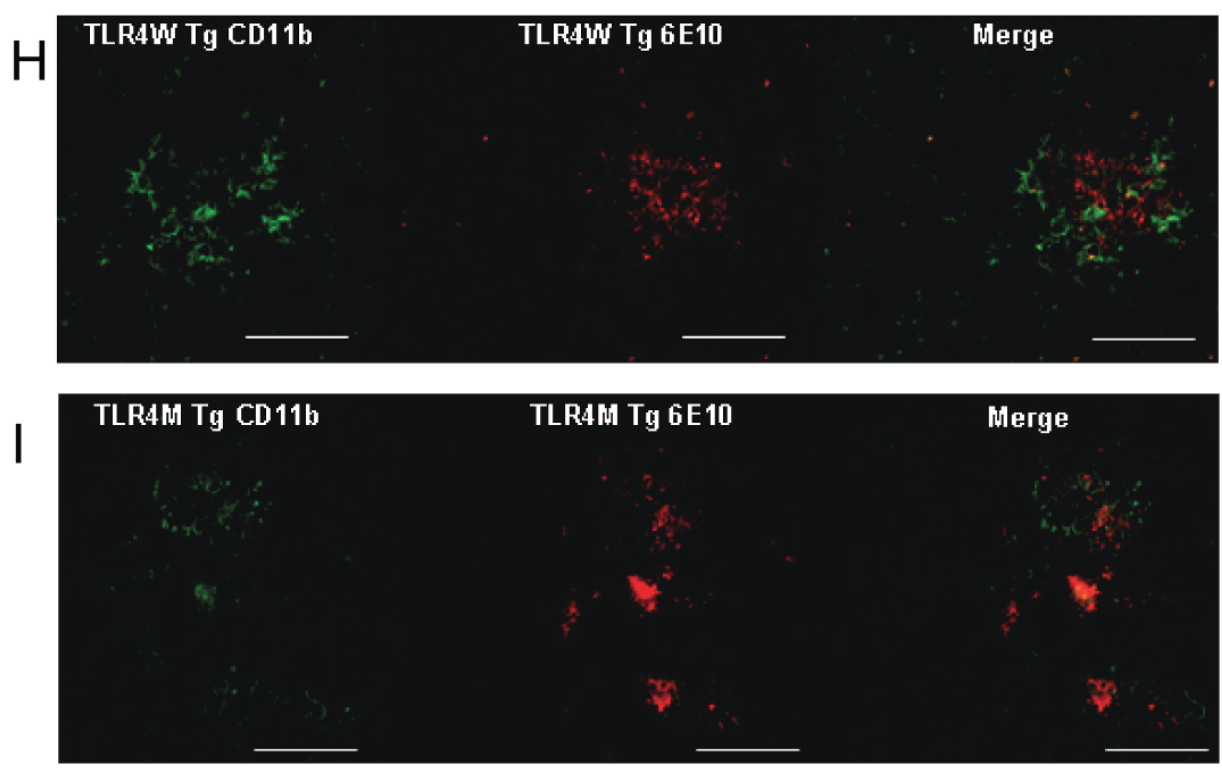

Figure 1 TLR4 mutation did not influence $A \beta$ load but diminished microglial activation in an AD mouse model at 5 months of age. A deposits in the brains of TLR4W Tg (A) and TLR4M Tg (B) mice were visualized by anti-A $\beta$ antibody (6E10). Activated microglia are visualized by anti-CD11b antibody in TLR4W Tg (C) and TLR4M Tg (D) mice. The inset image (C) is a higher magnification of the area indicated by the square. (E) Cerebral A $\beta$ plaques are visualized by $6 \mathrm{E} 10$ and average percentages of $A \beta$-immunoreactive areas in the cerebral cortex are shown as a bar graph (means \pm SEM). Average percentages of immunoreactive areas in the cerebral cortex for an activated microglial marker, CD11b (F), are shown as a bar graph (means \pm SEM). The ratio of CD11 b-immunoreactive area to 6E10-immunoreactive area in the cerebral cortex (G) are shown as a bar graph (means \pm SEM). Brain sections from 5-month-old TLR4W Tg $(\mathrm{H})$ and TLR4M Tg (I) mice were subjected to double-label fluorescence immunohistochemistry using anti-CD11b (green) antibody and 6 E10 (red). * $P \leq 0.05$. Scale bars $200 \mu \mathrm{m}$ for $A$ through $D, 50 \mu m$ for $\mathrm{H}$ and $\mathrm{I}$, and $10 \mu \mathrm{m}$ for the inset. 

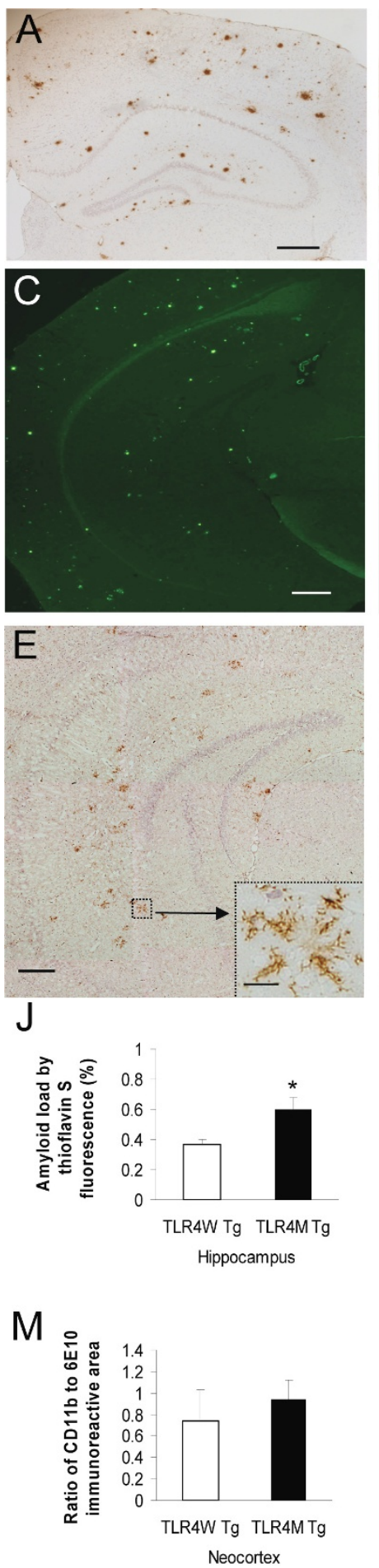
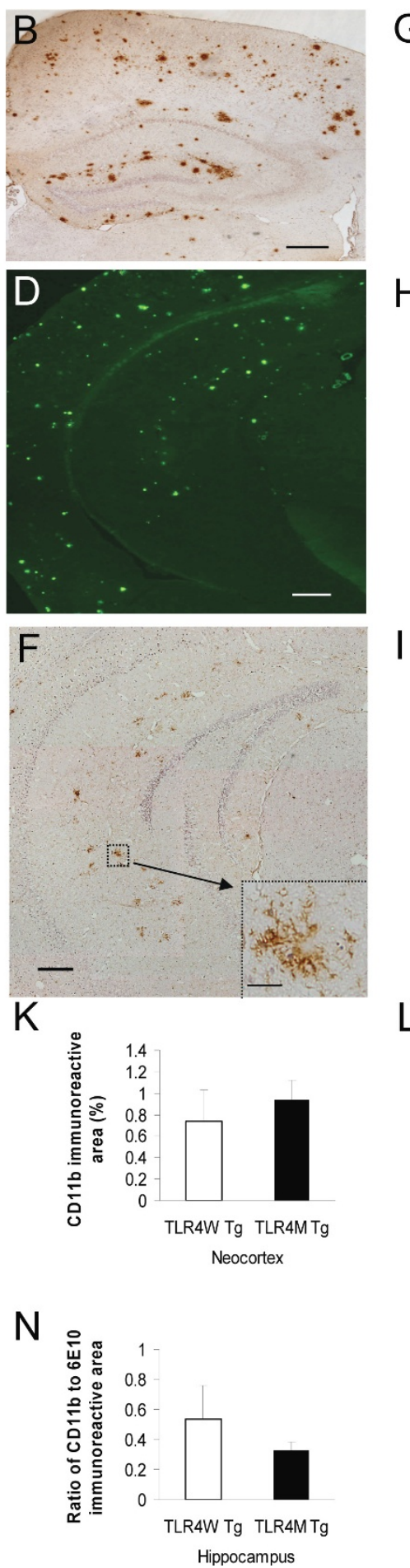
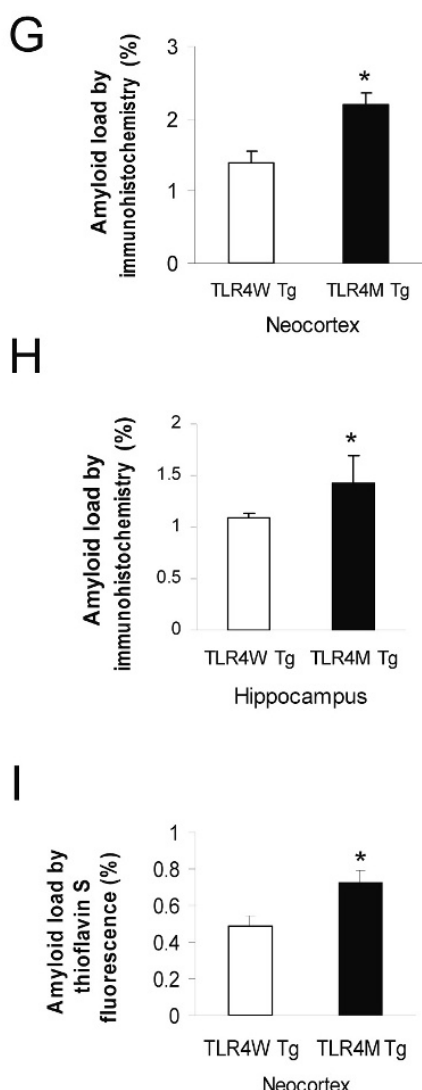

$\mathrm{H}$

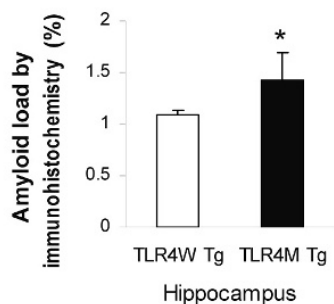

Neocortex

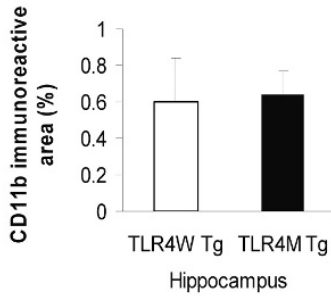

Figure 2 TLR4 mutation increased $A \beta$ load in the brain of an AD mouse model at $\mathbf{9}$ months of age. A $\beta$ plaques in the brains of TLR4W $\operatorname{Tg}(A$ and $C)$ and TLR4M Tg (B and D) mice were visualized by 6E10 immunohistochemistry and thioflavin S fluorescence, respectively. Average percentages of areas showing $A \beta$ immunoreactivity and fluorescence in the neocortex (G and I) and hippocampus ( $\mathrm{H}$ and $\mathrm{J}$ ) are shown as a bar graph (means \pm SEM). Activated microglia were detected by anti-CD11b antibody in TLR4W Tg (E) and TLR4M Tg (F) mice. The inset images (E and F) are a higher magnification of the areas indicated by the squares. Average percentages of CD11b-immunoreactive areas in the neocortex $(\mathrm{K})$ and hippocampus $(\mathrm{L})$ are shown as a bar graph (means \pm SEM). The ratio of CD11b-immunoreactive area to 6 E10-immunoreactive area in the neocortex $(M)$ and hippocampus $(N)$ are shown as a bar graph (means \pm SEM). ${ }^{*} P<0.05$. Scale bars $200 \mu m$ for $A$ through $F$ and $10 \mu m$ for the insets. 
difference between TLR4M and TLR4W Tg mice in the cerebral buffer-soluble $\mathrm{A} \beta 40$ content $(183.2 \pm 24.5 \mathrm{pg} /$ $\mathrm{mg}$ protein and $218.6 \pm 32.0 \mathrm{pg} / \mathrm{mg}$ protein, respectively, $P>0.05$ ) (Figure 3).

\section{Amyloid plaques are associated with activated microglia expressing TLR4}

A $\beta$ deposits have been shown to be closely associated with activated microglia and reactive astrocytes. To assess whether $A \beta$ deposition in the brain can recruit microglia and astrocytes expressing TLR4, we performed a colocalization analysis using anti-CD11b, anti-CD45 (a transmembrane protein tyrosine phosphatase specific for migratory leukocytes including activated microglia), anti-GFAP (an astrocyte-specific intermediate filament protein) and antiTLR4 antibodies. Brain sections from 9-month-old TLR4W Tg mice were double-stained with anti-TLR4 antibody and 1of 3 antibodis (anti-CD11b, anti-CD45, or anti-GFAP antibody). One brain section was statined with both anti-CD11b antibody and thioflavin S. Almost all fibrillar $\mathrm{A} \beta$ deposits stained with thioflavin $\mathrm{S}$ were closely accompanied by CD11b-immunoreactive microglia (Figure 4A, B and 4C). Immunofluorescence staining of the brain sections revealed that $\mathrm{CD} 11 \mathrm{~b}$ - and CD45-positive microglia co-expressed TLR4 (Figure 4D, E and 4F for CD11b, and $\mathrm{G}, \mathrm{H}$ and I for CD45) whereas limited expression of TLR4 was found in GFAP-positive astrocytes (Figure 4J, K and $4 \mathrm{~L})$.

TLR4 mutation makes an AD mouse model vulnerable to cognitive deficits in the Morris water maze

We previously reported that the APPswe/PS1dE9 transgenic mice had spatial learning and memory deficits by the Morris water maze at 12 months of age but not at 7 months $[17,18]$. Because soluble $A \beta 42$ is thought to be neurotoxic and levels of soluble A $\beta 42$ in the brains of 9month-old TLR4M Tg mice increased compared to those in TLR4W Tg mice, we evaluated the effects of

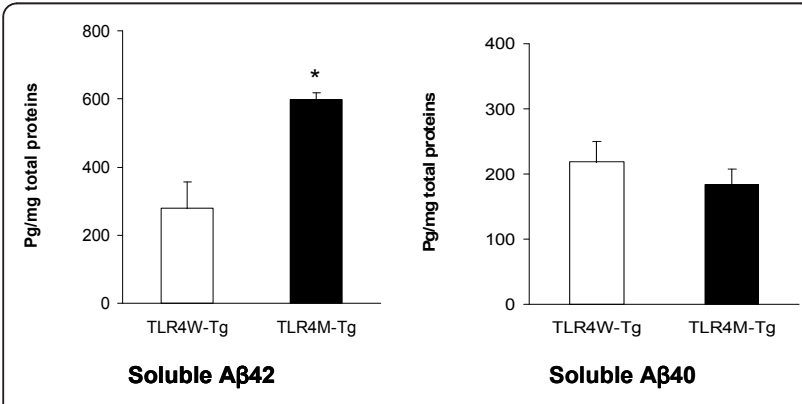

Figure 3 TLR4 mutation increased cerebral buffer-soluble A $\beta 42$ in an AD mouse model at $\mathbf{9}$ months of age. The cerebral buffersoluble $A \beta 42$ and $A \beta 40$ contents in TLR4W and TLR4M Tg mice were quantified by ELISA. The results are shown as bar graphs (means \pm SEM pg/mg total protein). ${ }^{*} P<0.01$ the TLR4 mutation on spatial learning and memory by the Morris water maze in the AD mouse model at 9 months of age. In the acquisition phase, three-way ANOVA with transgene and TLR4 as main factors and days as the repeated measure revealed significant TLR4 $\left(\mathrm{F}_{(1,36)}=5.46, P<0.05\right)$ and day $\left(\mathrm{F}_{(1,144)}=19.72, P<\right.$ $0.001)$ effects for path lengths as well as TLR4 ( $\mathrm{F}_{(1,36)}$ $=5.50, P<0.05)$ and day $\left(\mathrm{F}_{(1,144)}=32.84, P<0.001\right)$ effects for escape latencies. Paired comparisons by oneway ANOVA revealed higher latencies on days 2 ( $\mathrm{F}(1$, 18) $=8.33, P<0.01)$ and $3\left(\mathrm{~F}_{(1,18)}=4.85, P<0.05\right)$ and higher path lengths on days $1\left(\mathrm{~F}_{(1,18)}=4.58, P<0.05\right)$ and $3\left(\mathrm{~F}_{(1,18)}=4.58, P<0.05\right)$ by TLR4M Tg mice $(\mathrm{n}$ $=10)$ than TLR4W Tg mice $(\mathrm{n}=10)$, indicating that mutated TLR4 led to poorer scores than wild-type TLR4 in APP/PS1 transgenic mice. Moreover, TLR4M Tg mice had higher escape latencies than TLR4M non-Tg mice $(\mathrm{n}=10)$ on days $1\left(\mathrm{~F}_{(1,18)}=5.97, P<0.05\right)$ and 3 $\left(\mathrm{F}_{(1,18)}=7.85, P<0.02\right)$ (Figure $5 \mathrm{~A}$ and $\left.5 \mathrm{~B}\right)$. No other group differences were found in the acquisition phase or in either the probe or visible platform subtasks. These data indicate that mutated TLR4 impaired acquisition in the early not the late stage of training and spared longterm memory, visual acuity, and swimming abilities.

$A \beta$ fibrils upregulate expression of certain cytokines and chemokines via TLR4 signaling in the hippocampus and splenic monocytes

Induction of TLR signaling by its ligands in macrophages/microglia culminates in activation of transcription factors that upregulate expression of certain cytokines and chemokines, which are required for protective immune responses to pathogens and efficient clearance of damaged tissues. Fibrillar $\mathrm{A} \beta$ can activate microglia through interaction with cell surface receptor complexes whose essential components include TLR4 [7-9]. Therefore, we determined levels of cytokines and chemokines in 5- and 9-month-old TLR4M ( $\mathrm{n}=5$ and 4 , respectively) and TLR4W ( $\mathrm{n}=6$ and 7 , respectively) Tg mice, which are possibly modulated by TLR signaling in the $\mathrm{AD}$ pathogenesis. Cycle threshold $(\mathrm{Ct})$ values of mRNAs for the cytokines and chemokines are provided in Table 2. At 5 months of age, mRNA levels of IL-6 in TLR4M Tg mice decreased compared with TLR4W Tg mice in the hippocampus (2-fold, $P=$ $0.01)$ but the difference in the neocortex was not significant $(P=0.18)$ (Figure 6$)$. There were no differences in mRNA levels of IL- $1 \alpha$, IL- $1 \beta$, TGF- $\beta$, CCL2, CCL3, CCL4, and CCL6 between the two groups at 5 months of age. At 9 months, mRNA levels of IL-1 $\beta$ (2.5-fold, $P<0.0005)$, CCL3 (3.5-fold, $P<0.05)$, and CCL4 (3-fold, $P<0.05$ ) decreased in TLR4M Tg mice as compared to those in TLR4W Tg mice in the hippocampus (Figure 6). In the neocortex, however, such 


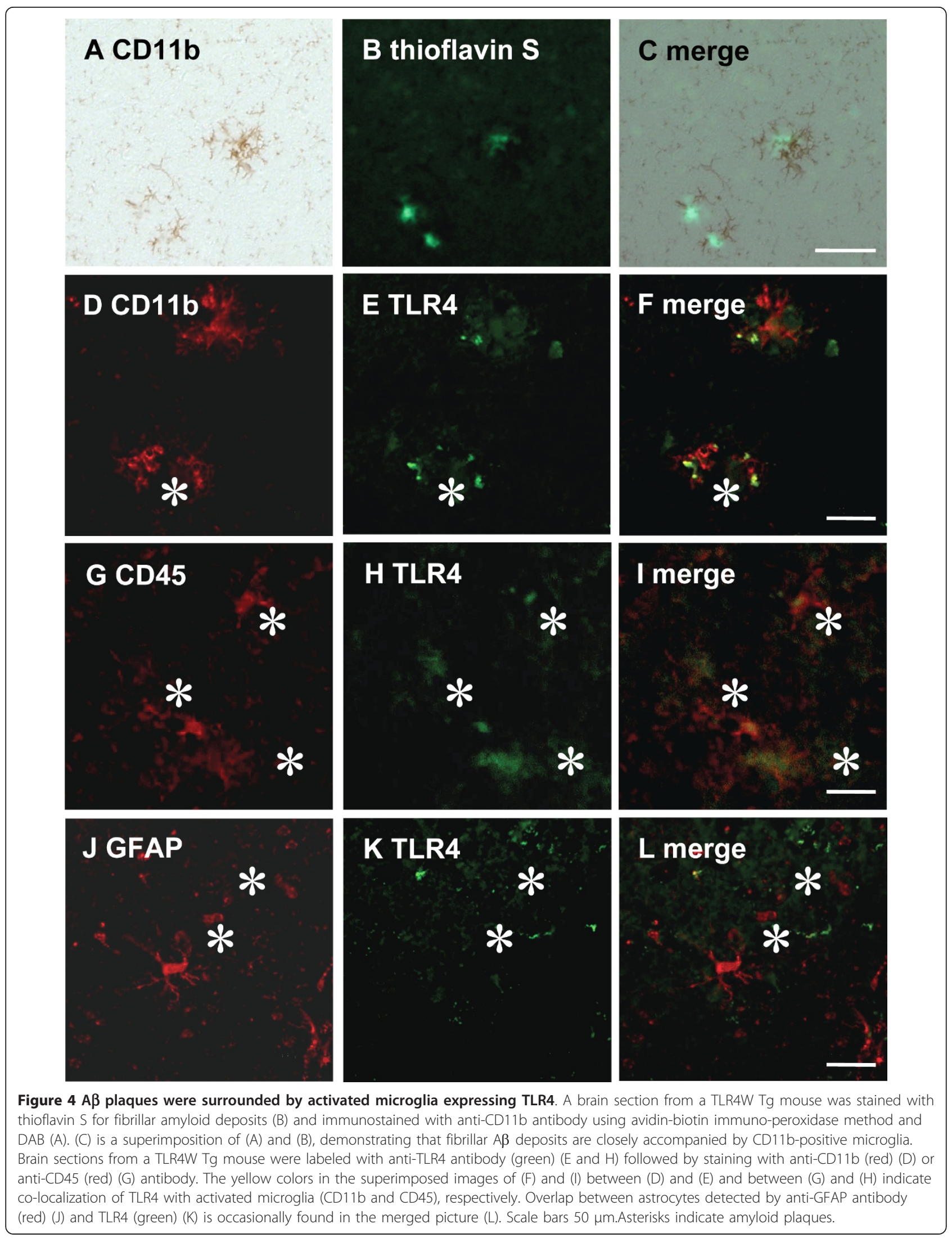




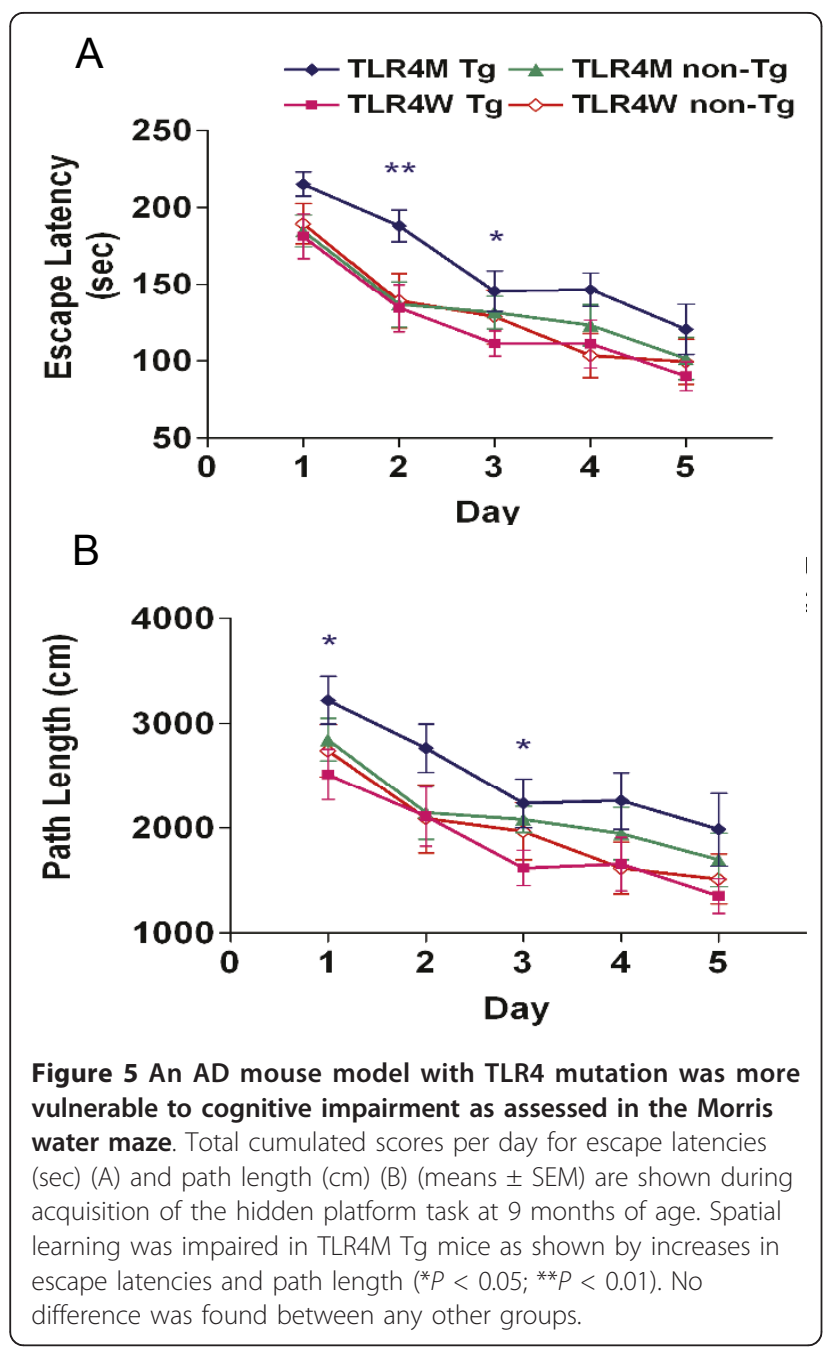

a decrease in 9-month-old TLR4M Tg mice was found only in the CCL3 mRNA levels (5-fold, $P=0.01$ ). Cerebral mRNA levels of IL-4, TNF- $\alpha$, and IFN- $\gamma$ were too low to satisfactorily make comparisons under the current experimental conditions.
Microglia are cells of myeloid origin and considered to be macrophages/monocytes in the central nervous system. Therefore, we have isolated $C D 11 b^{+}$splenocytes (monocytes) from 2-month-old TLR4W and TLR4 M Tg mice by fluorescence-activated cell sorting (FACS). After treating $\mathrm{CD}_{11} \mathrm{~b}^{+}$cells with fibrillar $\mathrm{A} \beta$, expression levels of cytokines and chemokines were determined by real-time PCR as described above. Ct values of mRNA for cytokines and chemokines are shown in Table 3. mRNA levels of IL- $1 \alpha$, IL-1 $\beta$, IL- 6 , CCL3 and CCL4 in fibrillar A $\beta$-treated TLR4M CD11 $\mathrm{b}^{+}$cells were significantly lower than those in fibrillar A $\beta$-treated TLR4W

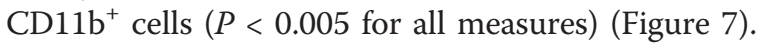

\section{Discussion}

Microglial activation and differentiation is complex and can produce diverse phenotypes depending upon their environments, pathogenic contexts, activating ligands and genetic backgrounds [19]. In $\mathrm{AD}$, activated microglia can be beneficial by clearing toxic $\mathrm{A} \beta$ assemblies and secreting neurotrophic factors [4,5]. On the other hand, activated microglia can be synapto- and neurotoxic by initiating and advancing the disease [3-5]. Little, however, is known about the mechanisms by which microglial activation states are orchestrated in AD. Here, we show that a nonfunctional mutation in the TLR4 gene diminished $A \beta$-induced microglial activation in AD model mice at 5 months of age when the AD model mice start to develop $A \beta$ deposits in the brain. There was no difference in the cerebral $A \beta$ deposits and buffer-soluble $A \beta$ amounts between TLR4W and TLR4M Tg mice in the very early stages of $\beta$-amyloidosis. Thus, TLR4 signaling did not alter $A \beta$ production and the onset of $A \beta$ deposition. We also demonstrate that 9-month-old TLR4M Tg mice had increases in the amounts of cerebral $A \beta$ deposits and soluble $A \beta 42$, which were associated with special learning deficits and reduced expression of CCL3. Thus, activation of microglia through TLR4 appears to be neuroprotective.

Table 2 Cycle threshold (Ct) values of mRNAs

\begin{tabular}{|c|c|c|c|c|c|c|c|c|c|c|}
\hline & & IL-1 $\alpha$ & IL-1ß & IL-6 & TGFß & $\begin{array}{c}\text { CCL2 } \\
\text { (MCP-1) }\end{array}$ & $\begin{array}{c}\text { CCL3 } \\
(\mathrm{MIP}-1 \alpha)\end{array}$ & $\begin{array}{c}\text { CCL4 } \\
\text { (MIP-1ß) }\end{array}$ & $\begin{array}{l}\text { CCL6 } \\
\text { (C10) }\end{array}$ & GAPDH \\
\hline \multirow{2}{*}{$\begin{array}{l}\mathbf{9 M} \\
\text { Neocortex }\end{array}$} & TLR4M & $5.7 \pm 0.35$ & 49 & $29.0 \pm 0.44$ & $2.3 \pm 0.39$ & .74 & $28.1 \pm 0.42$ & $28.6 \pm 0.37$ & $23.5 \pm 0.50$ & $13.2 \pm 0.22$ \\
\hline & 1 & 8 & 0 & 5 & 0 & 3 & 36 & 29 & 23 & 30 \\
\hline \multirow[t]{2}{*}{ Hippocampus } & TLR4M & $5.5 \pm 0.49$ & $29.8 \pm 0.57$ & $29.2 \pm 0.41$ & $.4 \pm 0.20$ & $28.03 \pm 0.25$ & $27.6 \pm 0.34$ & $29.2 \pm 0.40$ & $23.1 \pm 0.22$ & $12.8 \pm 0.33$ \\
\hline & TLR4W & $24.1 \pm 0.29$ & $27.4 \pm 0.09$ & $28.2 \pm 0.13$ & $20.6 \pm 0.07$ & $27.7 \pm 0.29$ & $24.7 \pm 0.37$ & $26.6 \pm 0.30$ & $20.7 \pm 0.24$ & $12.6 \pm 0.35$ \\
\hline \multirow{2}{*}{$\begin{array}{l}\mathbf{5 M} \\
\text { Neocortex }\end{array}$} & TLR4M & $29.2 \pm 0.50$ & $29.5 \pm 0.54$ & $29.1 \pm 0.45$ & $23.2 \pm 0.41$ & $31.6 \pm 0.93$ & $27.4 \pm 0.51$ & $28.9 \pm 0.42$ & $24.24 \pm 0.23$ & $15.5 \pm 0.45$ \\
\hline & TLR4W & $27.5 \pm 0.20$ & $28.9 \pm 0.24$ & $27.1 \pm 0.28$ & $21.9 \pm 0.10$ & $29.5 \pm 0.83$ & $26.8 \pm 0.13$ & $27.7 \pm 0.44$ & $22.6 \pm 0.29$ & $14.6 \pm 0.43$ \\
\hline \multirow[t]{2}{*}{ Hippocampus } & TLR4M & $26.2 \pm 0.34$ & $29.2 \pm 0.33$ & $28.2 \pm 0.06$ & $22.0 \pm 0.40$ & $28.3 \pm 0.49$ & $26.9 \pm 0.62$ & $29.0 \pm 0.48$ & $23.8 \pm 0.34$ & $14.1 \pm 0.22$ \\
\hline & TLR4W & $24.9 \pm 0.24$ & $28.4 \pm 0.24$ & $27.2 \pm 0.15$ & $21.3 \pm 0.22$ & $26.9 \pm 0.32$ & $25.7 \pm 0.54$ & $28.5 \pm 0.40$ & $23.2 \pm 0.69$ & $14.0 \pm 0.06$ \\
\hline
\end{tabular}



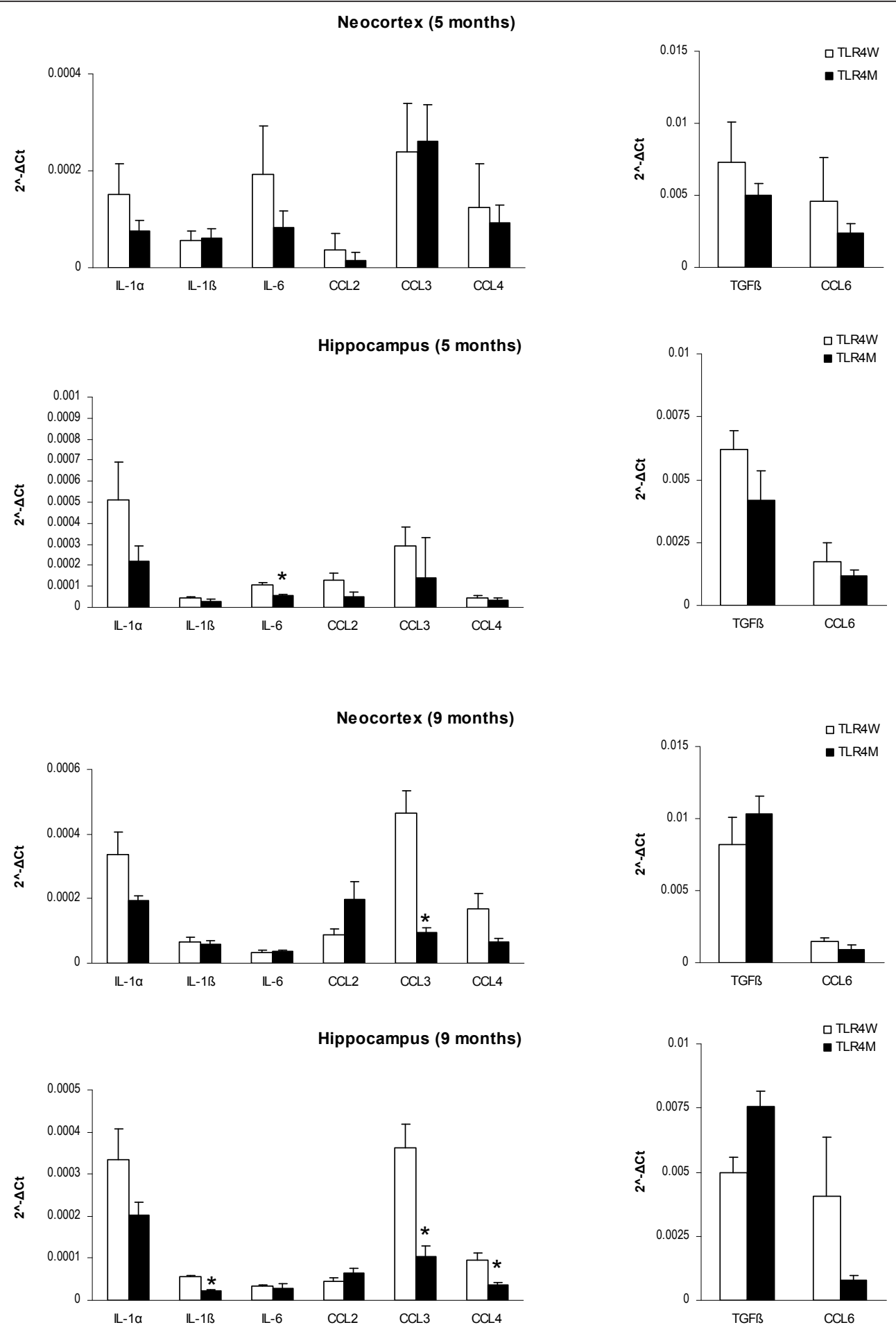

Figure 6 TLR4 mutation decreased expression levels of IL-1 $\beta$, CCL3 and CCL4 in an AD mouse model at 9 months of age. mRNA levels of cytokines and chemokines in the neocortex and hippocampus from TLR4W and TLR4M Tg mice at age 5 and 9 months were determined by real-time PCR using CDNA prepared by reverse-transcription of mRNA. mRNA levels of cytokines and chemokines were normalized by subtracting cycle threshold (Ct) values obtained with GAPDH mRNA and are shown as $2^{-\Delta C t}[\Delta C t=C t$ (cytokine or chemokine) - Ct (GAPDH)] (means \pm SEM). ${ }^{*} P<0.05$ 
Table 3 Cycle threshold (Ct) values of mRNAs from CD11b positive cells

\begin{tabular}{ccccccc}
\hline & IL-1 $\boldsymbol{\alpha}$ & IL-6 & CCL4 & CCL3 & IL-1 $\boldsymbol{\beta}$ & GAPDH \\
\hline TLR4M & $27.7 \pm$ & $31.2 \pm$ & $29.3 \pm$ & $28.1 \pm$ & $24.6 \pm$ & $20.2 \pm$ \\
& 0.10 & 0.40 & 0.76 & 0.13 & 0.06 & 0.09 \\
\hline TLR4W & $25.9 \pm$ & $26.4 \pm$ & $26.2 \pm$ & $23.2 \pm$ & $21.6 \pm$ & $19.1 \pm$ \\
& 0.08 & 0.46 & 0.15 & 0.06 & 0.25 & 0.06 \\
\hline
\end{tabular}

We previously reported that APPswe/PS1dE9 transgenic mice had spatial learning and memory deficits at 12 months of age but not at 7 months as assessed by the Morris water maze $[17,18]$. In line with these observations spatial learning deficits were not found in TLR4W Tg mice at 9 months of age but were apparent in TLR4M Tg mice of the same age. Thus, mice with the TLR4 mutation appeared more vulnerable to cognitive deficits associated with the APPswe/PS1dE9 transgenes. The cognitive deficits in 9-month-old TLR4M Tg mice may be attributable to an increase in the cerebral $A \beta$ load, particularly soluble $A \beta 42$. $A \beta 42$ is thought to be more pathogenic than $A \beta 40$ and an increase in the $A \beta 42$ to $A \beta 40$ ratio stabilizes toxic soluble $A \beta$ oligomers [20]. Soluble oligomeric $A \beta$ species have been identified as synapto- and neurotoxic forms of $A \beta$ rather than insoluble amyloid fibrils [21-23]. Soluble oligomeric $A \beta$ levels are elevated in the brains of $\mathrm{AD}$ patients and correlate with cognitive dysfunction [24]. Meyer-Luehmann et al. [13] hypothesize that amyloid plaques act as a local source of soluble $A \beta$ causing neuritic alterations. It is thus tempting to hypothesize that activated microglia through TLR4 ligation protect neurons from toxic oligomeric $A \beta$ which is released or produced from amyloid plaques by clearing $A \beta$ oligomers and deposits.

We found an increase in the cerebral $A \beta$ load in TLR4M Tg mice at 9 months of age but not at 5 months. Microglial activation associated with $A \beta$ deposits diminished in TLR4M Tg mice at 5 months. Our results are concordant with the observations from in vitro experiments by several other groups $[7,9,25]$ that fibrillar $A \beta$ activates microglia through interaction with its cell surface receptor complex to facilitate $A \beta$ phagocytosis and further, that TLR4 is required for fibrillar $A \beta$-induced activation of microglia as part of the receptor complex in vitro. However, there is no difference in the A $\beta$ load between TLR4W and TLR4M Tg mice at 5 months when amyloid deposition starts. A $\beta$ clearance by activated microglia in vivo may be slow as suggested by Meyer-Luehmann et al. [13]. Thus, the difference in the $A \beta$ load may be indiscernible in early stages of $A \beta$ deposition and gradually become evident by 9 months of age.

Fibrillar $\mathrm{A} \beta$ activates microglia/monocytes through TLR4 and induces expression of cytokines in vitro $[7,9,24]$. In spite of diminished microglial activation detected by CD11b expression in 5-month-old TLR4M Tg mice, levels of cytokine and chemokine expression were not altered except IL-6 in the hippocampus. Because $A \beta$ deposition starts to develop in this $A D$ mouse model at 5 months, the differences in the cytokine and chemokine levels may be too small to be detected. Alternatively, CD11b-positive microglia do not substantially produce the investigated cytokines and chemokines at early stages of $\beta$-amyloidosis in vivo.

Expression levels of IL-1 $\beta$ and CCL4 in 9-month-old TLR4M Tg mice reduced in the hippocampus but not in the neocortex. A consistent decrease in both hippocampus and neocortex of 9-month-old TLR4M Tg mice was found only in expression levels of CCL3. CCL3 is a member of the $\mathrm{CC}$ chemokine subfamily and its main function is the recruitment of leukocytes to the site of inflammation. $A \beta$ has been shown to induce microglial CCL3 expression and monocyte migration in vitro

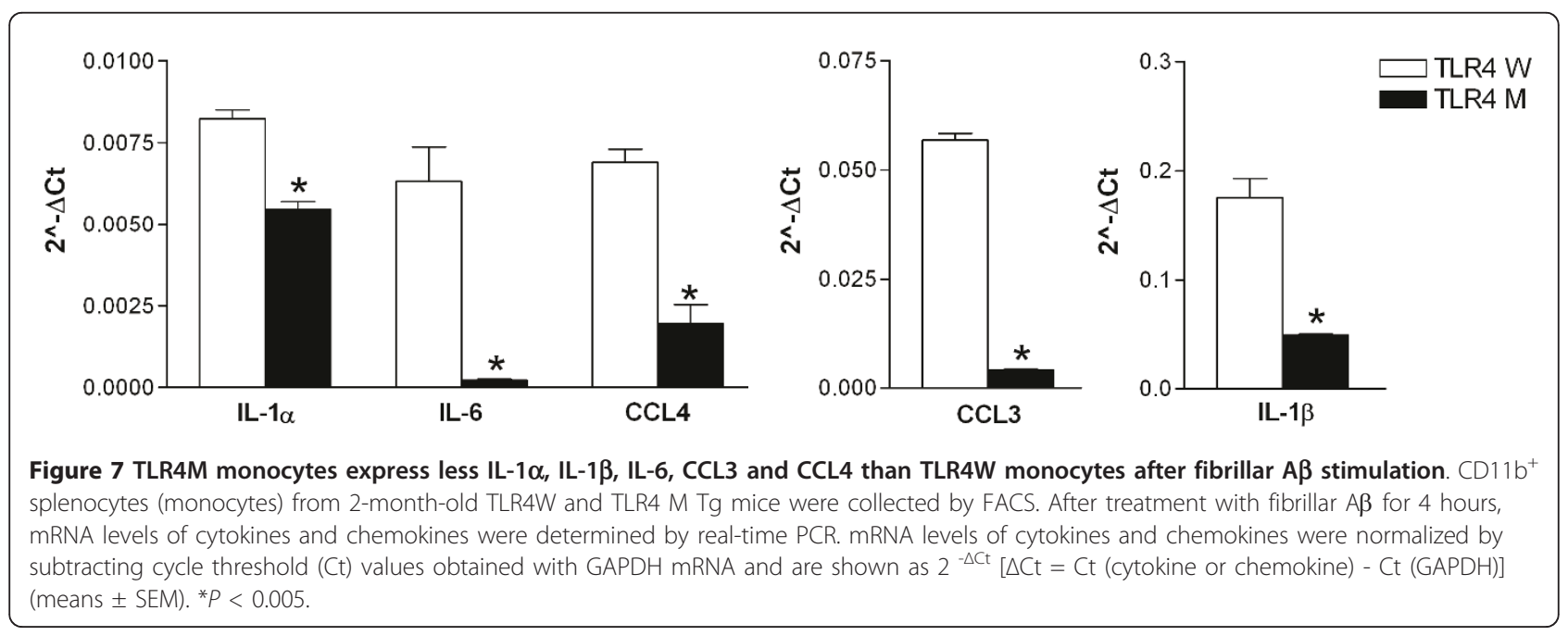


[26-28]. Intrahippocampal injection of $A \beta$ also induces microglial CCL3 expression and transendothelial migration of $\mathrm{T}$ cells in rodents [29-31]. Thus, a decrease in CCL3 expression in TLR4M Tg mice may diminish recruitment of bone-marrow derived microglia/monocytes. Bone-marrow derived microglia/macrophages have been shown to be very efficient in restricting the growth of amyloid plaques but resident microglia are not [32]. Furthermore, exercise decreases the cerebral $A \beta$ load in an AD mouse model, which is accompanied by an increase in cerebral CCL3 levels [33]. Here, we demonstrated TLR4 mutation diminished fibrillar A $\beta$ induced CCL3 expression in monocytes, suggesting that TLR4 signaling may play an important role in recruitment of microglia/monocytes. Therefore, the decrease in CCL3 expression in 9-month-old TLR4M Tg mice may contribute to the increase in the cerebral $A \beta$ load. It would be interesting to determine the role of CCL3 in cerebral $\beta$-amyloidosis by under- and over-expression of CCL3 in the brains of AD mouse models.

TLR2 deficiency (TLR2-/-) in an AD mouse model also increased soluble $A \beta 42$ in the brain and exacerbated cognitive impairments [34]. Furthermore, injection of CPG oligodeoxynucleotides, a TLR9 ligand, reduced $A \beta$ load in the brain and restored cognitive deficits in an AD mouse model $[35,36]$. These results suggest that activation of TLRs can be a therapeutic option for AD.

\section{Conclusion}

In summary, our results suggest that TLR4 signaling is not involved in initiation of $A \beta$ deposition and that microglia are activated and recruited in response to $A \beta$ deposition via TLR4 signaling to promote $A \beta$ clearance, resulting in protection of neurons from $A \beta$-mediated neurotoxicity. Because $A \beta$ fibrils upregulate expression of CCL3 in myeloid cells through TLR4 activation, CCL3 may be involved in microglial recruitment and A $\beta$ clearance. Thus, activation of microglia via TLR4 in early stages of $\mathrm{AD}$ pathogenesis is neuroprotective and TLR4 signaling pathways offer potential therapeutic targets.

\section{Abbreviations \\ AD: Alzheimer's disease; ANOVA: analysis of variance; APP: Aß-protein precursor; BSA: bovine serum albumin; ELISA: enzyme-linked immunosorbent assay; GAPDH: Glyceraldehyde 3-phosphate dehydrogenase; IFN: interferon; IL: interleukin; PS1 and PS2: presenilin 1 and 2; PCR: polymerase chain reaction; SEM: standard error of the mean; TBS: tris-buffered saline; TGF: transforming growth factor; TNF: tumor necrosis factor; TLR: toll-like receptor.}

\section{Acknowledgements}

We thank Drs. David Borchelt and Joanna Jankowsky for providing the TgAPPswe/PS1dE9 mice, Peggy Mankin for assisting with flow cytometry, and Linda Walter for help with preparing this manuscript. This work was supported in part by grants from the National Institutes of Health (AG030399, AG031979, AG029818 and EY018478) and the Alzheimer's Association (IIRG-07-59494).

\section{Author details}

1Department of Cancer Biology and Pharmacology, University of Illinois College of Medicine at Peoria, P.O. Box 1649, Peoria, IL 61656, USA. ${ }^{2}$ Department of Medical Genetics, Third Military Medical University, Chongqing 400038, PR China. ${ }^{3}$ Department of Environmental Health Science, New York Medical College, Valhalla, New York 10595, USA. ${ }^{4}$ CHUM/St-Luc, Neuroscience Research Center, Department of Medicine, University of Montreal, Montreal, Canada H2X 3J4. ${ }^{5}$ Faculté de Médecine et de Pharmacie, Université de Rouen, 76821 Mont Saint Aignan, Cedex, France.

\section{Authors' contributions}

$\mathrm{KF}$ and $\mathrm{RL}$ designed the study and reviewed the data. MS, JJ, JL, JK, HK, RL and $\mathrm{KF}$ analyzed the data and wrote the manuscript. JJ, MS, JL, JK, AP, JAR, $K T$, and HK performed experiments. All authors have read and approved the final version of the manuscript.

\section{Competing interests}

The authors declare that they have no competing interests.

Received: 13 January 2011 Accepted: 9 August 2011

Published: 9 August 2011

\section{References}

1. Hardy J, Selkoe DJ: The amyloid hypothesis of Alzheimer's disease: progress and problems on the road to therapeutics. Science 2002, 297:353-356.

2. Bertram L, Tanzi RE: Thirty years of Alzheimer's disease genetics: the implications of systematic meta-analyses. Nat Rev Neurosci 2008, 9:768-778

3. Wyss-Coray T: Inflammation in Alzheimer disease: driving force, bystander or beneficial response? Nat Med 2006, 12:1005-1015.

4. Rivest S: Regulation of innate immune responses in the brain. Nat Rev Immunol 2009, 9:429-439.

5. Mandrekar-Colucci S, Landreth GE: Microglia and inflammation in Alzheimer's disease. CNS Neurol Disord Drug Targets 2010, 9:156-167.

6. Takeuchi O, Akira S: Pattern recognition receptors and inflammation. Cell 2010, 140:805-820

7. Liu Y, Walter S, Stagi M, Cherny D, Letiembre M, Schulz-Schaeffer W, Heine H, Penke B, Neumann H, Fassbender K: LPS receptor (CD14): a receptor for phagocytosis of Alzheimer's amyloid peptide. Brain 2005, 128:1778-1789.

8. Stewart CR, Stuart LM, Wilkinson K, van Gils JM, Deng J, Halle A, Rayner KJ, Boyer L, Zhong R, Frazier WA, Lacy-Hulbert A, El KJ, Golenbock DT, Moore KJ: CD36 ligands promote sterile inflammation through assembly of a Toll-like receptor 4 and 6 heterodimer. Nat Immunol 2010, 11:155-161.

9. Reed-Geaghan EG, Savage JC, Hise AG, Landreth GE: CD14 and toll-like receptors 2 and 4 are required for fibrillar A\{beta\}-stimulated microglial activation. J Neurosci 2009, 29:11982-11992.

10. Tahara K, Kim HD, Jin JJ, Maxwell JA, Li L, Fukuchi Kl: Role of toll-like receptor signalling in A\{beta\} uptake and clearance. Brain 2006 129:3006-3019.

11. Jin JJ, Kim HD, Maxwell JA, Li L, Fukuchi Kl: Toll-like receptor 4-dependent upregulation of cytokines in a transgenic mouse model of Alzheimer's disease. J Neuroinflammation 2008, 5:23.

12. Heneka MT, Sastre M, Dumitrescu-Ozimek L, Dewachter I, Walter J, Klockgether T, Van Leuven F: Focal glial activation coincides with increased BACE1 activation and precedes amyloid plaque deposition in APP[V717I] transgenic mice. J Neuroinflammation 2005, 2:22.

13. Meyer-Luehmann M, Spires-Jones TL, Prada C, Garcia-Alloza M, De Calignon A, Rozkalne A, Koenigsknecht-Talboo J, Holtzman DM, Bacskai BJ, Hyman BT: Rapid appearance and local toxicity of amyloid-beta plaques in a mouse model of Alzheimer's disease. Nature 2008, 451:720-724.

14. Yan P, Bero AW, Cirrito JR, Xiao Q, Hu X, Wang Y, Gonzales E, Holtzman DM, Lee JM: Characterizing the appearance and growth of amyloid plaques in APP/PS1 mice. J Neurosci 2009, 29:10706-10714.

15. Jankowsky JL, Fadale DJ, Anderson J, Xu GM, Gonzales V, Jenkins NA, Copeland NG, Lee MK, Younkin LH, Wagner SL, Younkin SG, Borchelt DR: Mutant presenilins specifically elevate the levels of the 42 residue betaamyloid peptide in vivo: evidence for augmentation of a 42-specific gamma secretase. Hum Mol Genet 2004, 13:159-170. 
16. Stine WB Jr, Dahlgren KN, Krafft GA, LaDu MJ: In vitro characterization of conditions for amyloid-beta peptide oligomerization and fibrillogenesis. J Biol Chem 2003, 278:11612-11622.

17. Lalonde R, Kim HD, Fukuchi K: Exploratory activity, anxiety, and motor coordination in bigenic APPswe + PS1/DeltaE9 mice. Neurosci Lett 2004 369:156-161

18. Lalonde R, Kim HD, Maxwell JA, Fukuchi K: Exploratory activity and spatial learning in 12-month-old APP(695)SWE/co+PS1/DeltaE9 mice with amyloid plaques. Neurosci Lett 2005, 390:87-92.

19. Hanisch UK, Kettenmann H: Microglia: active sensor and versatile effector cells in the normal and pathologic brain. Nat Neurosci 2007, 10:1387-1394

20. Kuperstein I, Broersen K, Benilova I, Rozenski J, Jonckheere W, Debulpaep M, Vandersteen A, Segers-Nolten I, Van Der WK, Subramaniam V, Braeken D, Callewaert G, Bartic C, D'Hooge R, Martins IC, Rousseau F, Schymkowitz J, De SB: Neurotoxicity of Alzheimer's disease Abeta peptides is induced by small changes in the Abeta(42) to Abeta(40) ratio. EMBO J 2010, 29:3408-3420.

21. Lambert MP, Barlow AK, Chromy BA, Edwards C, Freed R, Liosatos M, Morgan TE, Rozovsky I, Trommer B, Viola KL, Wals P, Zhang C, Finch CE, Krafft GA, Klein WL: Diffusible, nonfibrillar ligands derived from Abeta1-42 are potent central nervous system neurotoxins. Proc Natl Acad Sci USA 1998, 95:6448-6453.

22. Walsh DM, Klyubin I, Fadeeva JV, Cullen WK, Anwyl R, Wolfe MS, Rowan MJ, Selkoe DJ: Naturally secreted oligomers of amyloid beta protein potently inhibit hippocampal long-term potentiation in vivo. Nature 2002, 416:535-539.

23. Lesne S, Koh MT, Kotilinek L, Kayed R, Glabe CG, Yang A, Gallagher M, Ashe $\mathrm{KH}$ : A specific amyloid-beta protein assembly in the brain impairs memory. Nature 2006, 440:352-357.

24. Tomic JL, Pensalfini A, Head E, Glabe CG: Soluble fibrillar oligomer levels are elevated in Alzheimer's disease brain and correlate with cognitive dysfunction. Neurobiol Dis 2009, 35:352-358.

25. Udan ML, Ajit D, Crouse NR, Nichols MR: Toll-like receptors 2 and 4 mediate Abeta(1-42) activation of the innate immune response in a human monocytic cell line. J Neurochem 2008, 104:524-533.

26. Fiala M, Zhang L, Gan X, Sherry B, Taub D, Graves MC, Hama S, Way D, Weinand M, Witte M, Lorton D, Kuo YM, Roher AE: Amyloid-beta induces chemokine secretion and monocyte migration across a human bloodbrain barrier model. Mol Med 1998, 4:480-489.

27. Ito S, Sawada M, Haneda M, Ishida Y, Isobe K: Amyloid-beta peptides induce several chemokine mRNA expressions in the primary microglia and Ra2 cell line via the PI3K/Akt and/or ERK pathway. Neurosci Res 2006 56:294-299.

28. Smits HA, Rijsmus A, van Loon JH, Wat JW, Verhoef J, Boven LA, Nottet HS: Amyloid-beta-induced chemokine production in primary human macrophages and astrocytes. J Neuroimmunol 2002, 127:160-168.

29. Passos GF, Figueiredo CP, Prediger RD, Pandolfo P, Duarte FS, Medeiros R Calixto JB: Role of the macrophage inflammatory protein-1alpha/CC chemokine receptor 5 signaling pathway in the neuroinflammatory response and cognitive deficits induced by beta-amyloid peptide. Am $J$ Pathol 2009, 175:1586-1597.

30. Man SM, Ma YR, Shang DS, Zhao WD, Li B, Guo DW, Fang WG, Zhu L Chen YH: Peripheral T cells overexpress MIP-1alpha to enhance its transendothelial migration in Alzheimer's disease. Neurobiol Aging 2007, 28:485-496.

31. Vincent VA, Selwood SP, Murphy GM Jr: Proinflammatory effects of M-CSF and A beta in hippocampal organotypic cultures. Neurobiol Aging 2002, 23:349-362.

32. Simard AR, Soulet D, Gowing G, Julien JP, Rivest S: Bone marrow-derived microglia play a critical role in restricting senile plaque formation in Alzheimer's disease. Neuron 2006, 49:489-502.

33. Nichol KE, Poon WW, Parachikova Al, Cribbs DH, Glabe CG, Cotman CW: Exercise alters the immune profile in Tg2576 Alzheimer mice toward a response coincident with improved cognitive performance and decreased amyloid. J Neuroinflammation 2008, 5:13.

34. Richard KL, Filali M, Prefontaine $P$, Rivest $S$ : Toll-like receptor 2 acts as a natural innate immune receptor to clear amyloid beta 1-42 and delay the cognitive decline in a mouse model of Alzheimer's disease. $J$ Neurosci 2008, 28:5784-5793.

35. Scholtzova H, Kascsak RJ, Bates KA, Boutajangout A, Kerr DJ, Meeker HC, Mehta PD, Spinner DS, Wisniewski T: Induction of toll-like receptor 9 signaling as a method for ameliorating Alzheimer's disease-related pathology. J Neurosci 2009, 29:1846-1854.

36. Doi Y, Mizuno T, Maki Y, Jin S, Mizoguchi H, Ikeyama M, Doi M, Michikawa M, Takeuchi H, Suzumura A: Microglia activated with the tolllike receptor 9 ligand $C p G$ attenuate oligomeric amyloid \{beta\} neurotoxicity in in vitro and in vivo models of Alzheimer's disease. Am J Pathol 2009, 175:2121-2132.

\section{doi:10.1186/1742-2094-8-92}

Cite this article as: Song et al.: TLR4 mutation reduces microglial activation, increases $A \beta$ deposits and exacerbates cognitive deficits in a mouse model of Alzheimer's disease. Journal of Neuroinflammation 2011 8:92.

\section{Submit your next manuscript to BioMed Central and take full advantage of:}

- Convenient online submission

- Thorough peer review

- No space constraints or color figure charges

- Immediate publication on acceptance

- Inclusion in PubMed, CAS, Scopus and Google Scholar

- Research which is freely available for redistribution

Submit your manuscript at www.biomedcentral.com/submit
Ciomed Central 